\title{
INDIAN LANDS: THEIR ADMINISTRATION WITH REFERENCE TO PRESENT AND FUTURE USE
}

By Hon. Francis E. Leupp, Commissioner of Indian Affairs, Washington, D. C.

From the genesis of the freehold the relation between land and the degree of civilization of the people living thereon has been very close. Economists have recognized this fact, and it has formed one of the premises of political economy from the founding of that science. That the welfare of a people has its tap-root literally in the soil has come to be regarded as axiomatic; hence it is that the administration of Indian lands constitutes a very large part of what is known as the "Indian Problem"- the effort of the United States, as guardian or trustee, to civilize the Indian race and make it selfsustaining.

It may be said in passing, and enlarged upon later, that the present administration of Indian affairs takes cognizance not only of the interests of the Indians, but also of those of the whites, and gives proper weight to the justifiable selfishness which insists upon such method of administering the lands of the Indian wards as will have due regard for the rights of their trustees.

It is impossible adequately and intelligently to discuss the present administration of Indian lands without a retrospective glance at the steps by which the policy now followed has been reached. At the time of the discovery and settlement of America the many Indian tribes inhabiting that part now embraced within the limits of the United States were recognized by the various governments under whose authority settlements by whites were made as separate and independent communities. As the country gradually filled up, and as the demands of increasing population required, the United States, which had succeeded in turn to the rights of Great Britain, Spain, France and Mexico, under the pressing necessity of obtaining complete possession of the territory east of the Mississippi, adopted the policy of extinguishing, by treaties, the title of the various tribes to the land they had occupied, assigning to each a district or reservation of land of smaller area, yet com- 
mensurate with the Indian modes of life and subsistence, within whose limits it was protected in the enjoyment of a modified or local sovereignty.

This was the beginning of the "Reservation System," a system whose evils it requires the larger part of the energy of recent Indian administration to remedy; and it is to be noted that in laying the foundation for this anomalous maintenance of nations within a nation, the Indians were not yet recognized as wards of the Government, but were treated with as distinct though dependent nations, and their right to the lands occupied by them was recognized in formal treaties. Most of the reservations, each a princely domain, were west of the Mississippi and on land for which it was then thought the white settler would have no need for centuries if at all; and the right of perpetual possession was guaranteed the Indians.

Then came the railroad and telegraph, and, almost overnight, wrought the changes of centuries under the old régime. When time and space had been annihilated, land which had been waste and useless suddenly became not only desirable but necessary for the extended development of the national interests.

As the whites increased in number and power and in time surrounded the reservations with farms and towns, they were prevented from entering and taking possession of the lands of the Indians only by an enforcement of treaty obligations. It was not long before the situation thus created was recognized as impossible, and under one and another pretext large areas of reservation land were thrown open to general settlement. With this change came also, partly under the guise of compensation for the lands thus taken, and partly as the simplest way of keeping alive a people whose means of subsistence, the hunt, had been destroyed, the abominable ration system, with its resultant pauperization of the Indian race. It will be seen before I close this discussion that much of the present method of administering Indian land matters is aimed at, or modified by, the necessity of combating the results of this deadly blow at the real welfare of the Indian.

Three epochal departures mark the transition from the method of treating the Indians and their lands which I have just outlined, to the present system. They are the Act of March 3, I87 I (16 Stat. L., 566), the Act of February 8, I887 (24 Stat. L., 388), and the $(621)$ 
decision of the United States Supreme Court in the case of Lone Wolf against Hitchcock rendered on January 5, 1903 .

The first of these, which declared that thereafter no Indian nation or tribe within the territory of the United States should be recognized as an independent nation or tribe with whom the United States might contract by treaty, was the initial step in the recognition of the ultimate use of Indian lands. By depriving the Indian tribes of the treaty-making status, Congress gave itself the power the more closely to scrutinize proposed contracts or agreements with them and to alter such agreements for the public good without the consent of the Indians.

The next step logically, though not chronologically, was the decision of the Supreme Court referred to, which held in effect that the United States was not bound to regard the terms of its treaties with Indians made prior to the Act of March 3, 1871, when the public welfare, or the real interest of the Indians, was no longer subserved by their observance. By this act and this decision the Government of the United States, largely represented in its relations with these people by the Office of Indian Affairs, was given the power, with the concomitant responsibility, of working out with a free hand the salvation of the Indians and the administration of their lands to the best interest of all concerned.

Midway in point of time between the act and the decision referred to came the Act of February 8,1887 , variously known as the "Dawes Bill," from its author, the late Senator Henry L. Dawes of Massachusetts, the "Severalty Law," and the "General Allotment Act," which provides that the President may, in his discretion, allot the Indians their lands in severalty in specified quantities, and that the surplus lands may then be disposed of in manner agreed upon, the proceeds going to the Indians.

Rightly understood, this act was the "Magna Charta" of the Indian, though the emancipation it brought was forced upon him reluctant and protesting, instead of being demanded by him. At the same time it provides automatically for opening to white settlement the thousands of acres of Indian land not actually needed by the Indians.

The Severalty Act was designed to change the wandering, improvident and semi-civilized hunter to a domestic, industrious and enlightened citizen. As the first step to this end the law contem- 
plated giving to each Indian a home, and that the home in the first instance should be agricultural. The first industries were to be the primal ones of farming and grazing. In this new mode of life the guardianship which theretofore had been exercised over the tribes was transferred to a guardianship over the individual allottees. The separate manhood of each Indian was recognized, but for a time he was to be subject to the care and supervision of the Government as trustee. Recognizing that the Indian could not be made overnight into a business man qualified to care for his own interests, the law was so conditioned that during a period of wardship and tutelage of at least twenty-five years the allottee should not be subject to entering into unequal competition with whites in the field of traffic and general business outside of agriculture and grazing. At the end of the twenty-five-year trust period, the Indian would be presumed to have advanced so far in civilization as to be competent to manage his own affairs, whereupon a fee patent would issue to him, and the leading-strings between himself and a paternal government would be severed finally.

The reservation system had the effect of stunting endeavor to the extent of suppressing the chief motive of human effort-selfpreservation. Moreover, bitter experience had led the Indian to conceive a racial dislike to the white man, whose good faith he suspected. By nature he is averse to common hard labor, has no idea of saving for to-morrow, and abhors restraint and discipline.

It is not to be wondered, therefore, that when the Allotment Act was passed, the red men evinced a sharp repugnance to the whole program contemplated. They objected to the disruption of the old tribal ties, to the distribution of their lands, and to the demand that they should farm. In many cases the greatest difficulty was experienced in inducing members of bands to take up their allotments. Even where reservations were broken up and the allotted land accepted, often no disposition was displayed by the allottees to compass the essential object of supporting themselves. They simply sat down and let things drift or indulged in their old time diversions of dancing and gambling, and in most cases the Government thought it expedient to continue the accustomed distribution of rations for a greater or less period.

For twenty-two years the Office of Indian Affairs has been engaged in the execution of the General Allotment Act, and various 
special acts having in view the same purpose but adapted to the varying conditions of different tribes. The general law, for example, provides for the allotment of eighty acres to each member of the tribe where the land is recognized as agricultural, and $I 60$ acres where it is fit only for grazing; but in a large part of the frontier West it has proved difficult to classify the lands satisfactorily.

Even where classification is simple the general law sometimes proves defective on other points. Most of the reservations yet to be allotted contain little or no agricultural land that can be cultivated without irrigation. Eighty acres of irrigable land is vastly more than an Indian can utilize, and, owing to lack of funds, the cost of irrigating so great an area is almost prohibitive. All who know Indians are aware that no people are so easily discouraged by being given a task which seems to them beyond their powers. Hence, in allotting to an Indian a tract of land larger than he can hope to tillespecially when his tenure of the water necessary to make it productive depends upon his beneficial and continued use thereofwould be to place upon him not only a physical but a moral handicap.

On the other hand, I60 acres of grazing land is entirely inadequate in those regions where the main industry is raising cattle. Where it requires forty acres to a head of cattle, and roo head of cattle to furnish means of support for a family, an allotment of 320 acres of grazing land will not solve that family's economic prob. lem.

Not infrequently where reservations are opened by special acts of Congress, the primary object appears to be to hasten the date when the surplus unallotted lands can be taken by the home-seeker, and not enough thought is given to the condition of the Indians to be allotted, or to the ultimate welfare of those whites who will acquire homes on the coveted lands or will eventually succeed, through purchase, to a large share of the allotments.

I think the remedy lies in vesting greater authority in the Department, by passing a general law allowing not less than five or more than forty acres of irrigable land, or more than 640 acres of grazing land, to each Indian, in the discretion of the Secretary of the Interior. This not only would enable the Department to care properly for the interests of the Indians, but would result also in the more rapid opening of reservations and the consequent dissolu- 
tion of the generally condemned reservation system. The development of the frontier West would thus proceed to the ultimate advantage of both Indian and white citizens, and automatically.

Like their white neighbors, Indians are of more than one sort, ranging from good degrees of intelligence, industry and thrift to the depths of helplessness, ignorance and vice. Experience has proved that Indians of the former class do better when allowed to run their own business than when the Government tries to run it for them; but that citizenship and jurisdiction of the local courts are of no advantage to Indians of the latter class because the community as a rule does not interest itself to compel the proper exercise of police and judicial powers in behalf of any group of people who constitute a mere waste element and bear no share of the tax burden.

Such conditions made plain the need of some law which would enable the Indian Office to manage the affairs of the helpless class with undisputed authority, but, on the other hand, to remove from the roll of dependents the ever-increasing number of Indians who no longer need Government supervision, yet who could be emancipated only by a special act in each case. To this need came a response from Representative Charles H. Burke of South Dakota, who procured the passage of an act modifying the Dawes law by postponing the citizenship of all Indians allotted after May 8, I906, till the termination of the trust period, but giving authority to the Secretary of the Interior to terminate the trust period by issuing a patent in fee whenever he is satisfied of the competency of any individual allottee to manage his own affairs. It also provides that on the death of an Indian allottee his allotment may be canceled and patent in fee issued for the canceled allotment to the heirs of the deceased allottee; or the Secretary of the Interior may cause the land to be sold as provided by law and issue a patent therefor to the purchaser, paying the net proceeds to the heirs or their legal representatives.

The legislation of recent years shows conclusively that the country is demanding an end of the Indian question, and this is right. The Burke law is accomplishing more in this direction than any other single factor developed within a generation. Competent Indians, owning their land in fee and receiving their portions of the tribal property without restrictions, cannot by any course of action maintain a claim for further consideration. Through such 
measures and their application, the grand total of the nation's wards is diminishing daily and with a growing ratio, more than 3500 applications for fee patents having been approved in the three years the Burke law has been in effect.

From what $I$ have written it will be seen that for twenty-two years the Indian department has been required to administer two classes of Indian lands-the reservations, and the lands held in trust for individual allottees-and it will be engaged in this dual work for a few years to come. After that there will be no reservations; white settlers will have all the surplus lands, their farms will join those of the Indians, and the latter, by the removal of restrictions, will pass rapidly from the trusteeship of the Government into the care of their owners; and thus, in about a generation, "Indian lands" and the "Indian problem" will simultaneously disappear in the vortex of a general American citizenship. Let me trace now, briefly, some of the specific methods employed in administering these two classes of lands.

I have said that the Indian was reluctant to use his land either for farming or for stock-raising. Partly as an example to arouse emulation and partly to prevent needless waste, the policy of leasing tribal lands was inaugurated, and this was the earliest use made of strictly reservation lands. This policy is still in vogue, and hundreds of such leases are made every year.

No authority existed for leasing allotted lands until February 28, I89I, when an amendment to the General Allotment Act provided for leasing allotments on reservations "bought and paid for" by the Indians. Under this act (26 Stat. L., 794), as amended by the Acts of June 7, I897 (30 Stat. L., 85), and May 31, I900 (3I Stat. L., 299), the terms for which allotted lands may be leased are limited to three years for grazing and five years for farming purposes, except unimproved allotments on the Yakima Reservation in Washington, which may be leased for agricultural purposes for a period not exceeding ten years, on such terms and conditions as may be prescribed by the Secretary of the Interior. The Act of April 30, Ig08 (35 Stat. L., 70), authorizes the leasing of allotted lands susceptible of irrigation in the former Uintah and Umcompahgre Reservations in Utah, with the consent of the allottees, for terms not exceeding ten years; and the same act extends the term for leasing lands susceptible of irrigation on the Shoshone Reservation in Wy- 
oming to not exceeding twenty years in the discretion of the Secretary of the Interior. More than 7300 such leases were approved between August 15, 1907, and August 15, 1908. My own modification of this policy, as Commissioner of Indian Affairs, has been to permit progressive allottees to make their own leases and collect their own rentals free from departmental supervision, and in the same period more than 2900 Indians have been accorded this privilege.

Next in order is the use of timber on reservations and allotments, and here enters what is perhaps the most important single policy in my handling of Indian affairs-a policy which has been extended to reclamation work, and which I hope to see made to cover many other phases of administration.

As to timber: The Indians have the right to apply to their own use and benefit the entire products of a reservation, whether the result of their own labor or of natural growth, if they do not commit waste. If the lands in a state of nature are not in a condition for profitable use, they may be made so; if wanted for the purpose of agriculture, they may be cleared of their timber to such an extent as may be reasonable under the circumstances, and the surplus timber thus removed and not required for use may be sold by the Indians.

There is no general law authorizing the sale of growing timber on Indian allotments and reservations. The Act of February I6, I889 (25 Stat. L., 673), provides that the dead timber, standing or fallen, may be cut and removed with the consent of the President. Under this act sales have been made from time to time.

Article 3 of the Treaty of September 30, I854 (Io Stat. L., I IO9), with the Chippewa Indians of Lake Superior and Mississippi, authorized allotments with only such restrictions as the President might see fit to impose. Under this article the President has approved regulations under which allottees of the Bad River, Lac du Flambeau, Lac Courte Orielles and Red Cliff Indians have been authorized to sell their timber.

The Act of April 21, I904 (33 Stat. L., 209), gave to the Chippewas of Minnesota the right to sell their timber on the allotted lands with the consent of the Secretary of the Interior, and under this act the Secretary has promulgated regulations for Indians of the Leech Lake, Grand Portage and Fond du Lac Reservations. 
Operations are now in progress on the Menominee Reservation in Wisconsin, under the terms of the Act of March 28, I908 (35 Stat. L., 6I), which authorizes the cutting of timber, the preservation of the forest and the manufacture and sale of lumber on that reservation.

The Supreme Court in United States vs. Paine Lumber Company (206 U. S., 467), decided that the Stockbridge and Munsee Indians in Wisconsin were authorized to sell the timber on their allotments without governmental supervision. Even with such limited authority millions of feet of timber are logged yearly, and the Department is endeavoring to obtain legislation authorizing the sale of mature timber on all Indian lands, whether allotted or unallotted.

Where the present administration has made its impress upon the forestry and other classes of work under its supervision is in the way of systematic co-operation between various departments and bureaus of the Government, so as to get rid of the "wheels within wheels" which are so grave a source of waste in administration For example, the Office of Indian Affairs, when I assumed charge of it, not only performed the functions naturally to be expected of a benevolent guardian engaged in raising a race of human beings from barbarism to civilization, but maintained a little forestry branch, a little reclamation service, and several other minor organizations for work along lines commonly cared for, and presumptively better cared for, by special bureaus established by law for the benefit of the American people at large. Recognizing the broad economic principle that no extensive public work can be conducted so successfully on a retail as on a wholesale basis, and as the needless multiplication of machinery . for doing the same class of work tends to retard rather than advance the attainment of the ends sought, I opened negotiations for a co-operative arrangement with the Forest Service, and under date of January 22, 1908, the Secretary of the Interior and the Secretary of Agriculture entered into an agreement by the terms of which the Forest Service is making a careful study of the forests on Indian reservations, for the purpose of determining the best permanent use of the lands. When these are found more valuable for forest purposes than any other, it prepares and applies plans for their management; it sells such timber as may be cut without injury to the forests; it supervises the logging under methods which will improve the forest and yield the full market 
value of all the timber cut; and it protects all forests on Indian reservations whether or not they are being cut over. While the salaries and expenses of the men employed to carry out this agreement are paid by the Indian Office, all the men employed are responsible only and directly to the Forest Service.

A still larger field for increased co-ordination is found in irrigation work which is going on now all over the West. Within the last ten years this subject has taken such strides in public interest as to astonish even those who are the most enthusiastic advocates of the artificial reclamation of our deserts. Irrigation has come to play so large a part in the agriculture of the West that it is almost impossible to separate the two ideas. Tracts of Indian country which were made into reservations long before there was any general knowledge of irrigation, and which were then supposed to be comparatively valueless except for grazing or mining, are now proving to be well adapted to general agriculture, even including some of its more delicate forms, if water can be put upon the soil.

The problems pertaining to the development and preservation of an adequate water supply for the irrigation of Indian lands are of a nature demanding the most careful study. The Indian Service has its own irrigation corps and system; but here again, as in matters affecting timber lands, the problems to be worked out on Indian reservations are often so closely allied with problems involving large areas of country opened to white settlement as to make the union of the Indian irrigation projects and the white irrigation projects really essential to the success of both.

To that end I have perfected an agreement with the Reclamation Service whereby there are turned over to that service those irrigation projects into which both white and Indian interests enter, reserving for the Indian Office those which are purely Indian propositions; but even in the latter class the irrigationists of the Indian Service have the benefit of the expert advice and assistance of the consulting engineers of the sister service. Such a combination procures for the Indians the best the Government can command in the way of irrigation plans and work, and reduces the chances of serious mistakes to a minimum. Under such conditions large works, involving the expenditure of several million dollars, mostly reimbursable from future sales, are under way or projected on the Gila River Reservation, Arizona, the Flathead, Blackfeet and Fort Peck Reser- 
vations in Montana, the Fort Hall Reservation in Idaho, the former Uintah Reservation in Utah, and the Shoshone or Wind River Reservation in Wyoming.

It is apparent that in the rapid opening of reservations, the severing of the tribal relations as far as possible, and the invitation to white occupancy of lands formerly locked within the confines of reservation boundaries, the protecting arm of the Government has been withdrawn in a large degree from the ward who heretofore has been so dependent upon it. Many problems will arise in the future, and it must needs be that some of the weaker of this race go down that their stronger fellows may attain to the full measure of citizenship. It is impossible to foresee all the difficulties which may present themselves, and they will have to be met as they arise in the manner which seems most equitable to all interests concerned.

But it must be apparent that through the present policy of the Government in administering Indian lands due regard is had to the proper interests of the whites. Any other policy would not result in the real betterment of conditions for the Indians, for it would unnecessarily retard the growth of the State or Territory within whose boundaries Indian lands lie, and the individual Indian, like the individual white, rises or falls in prosperity with the prosperity of the community in which he lives and of the country which surrounds him. 